\title{
Small-sided games for technical and tactical development in young rink hockey players Juegos reducidos para el desarrollo técnico de jóvenes jugadores de hockey sobre patines *Samuel Honório, *Marco Batista, *Jorge Santos, *João Serrano, * João Petrica, **João Almeida, **Miguel Camões \\ *Polytechnic Institute of Castelo Branco (Portugal), ** Polytechnic Institute of Viana do Castelo (Portugal)
}

\begin{abstract}
Rink hockey like any other team sport game is necessary to have a mastery of the game object «the ball» and for this it is necessary that athletes do not have a deficient training steps in that process, because it is during their development, that the athlete is in an optimal situation to improve on this aspect of the game. The study objective was to identify which game model allows young athletes to have a greater number of interactions with the ball in rink hockey in the levels of «Under 8» and «Under 10». Our study sample consisted of 24 games: 8 games in the $3 \times 3$ model; 8 games in the $4 \times 4$ model and 8 games in the $5 \times 5$ model. The 24 matches are equally divided by the levels of Under 8 and Under 10 with a total of 88 children participating. For data collection instrument we used the deferred observation method where we proceeded to a descriptive analysis of the data to find the means, standard deviation and totals of: Shots, Passes, Interceptions and Goals. The Mann-Whitney and Kruskal-Wallis tests were used for comparisons and for correlations, the Spearman'sTest was used to verify whether as the playing area available to the player increased, the player's actions increased as well. The $3 \times 3$ model obtained a total of 911 actions, the $4 \times 4$ model obtained 923 and the $5 \times 5$ game model obtained 799 game actions. The $4 \times 4$ game model obtained the highest total number of game actions in all levels analysed suggesting that the implementation of this model brings benefits to the athletes.
\end{abstract}

Keywords: Hockey; Small-sided games; Training Levels; Children; Game Models.

Resumen. El hockey sobre patines como cualquier otro deporte de equipo es necesario para tener un dominio del objeto de juego «la pelota» y para ello es necesario que los deportistas no tengan unos pasos de entrenamiento deficientes en ese aspecto, pues es durante su desarrollo, que el atleta se encuentra en una situación óptima para mejorar en este aspecto del juego. El objetivo del estudio fue identificar qué modelo de juego permite a los jóvenes deportistas tener un mayor número de interacciones con el balón, en los niveles de «Menos de 8 » «Menos de 10». Nuestra muestra de estudio consistió en 24 juegos: 8 juegos en el modelo $3 \times 3$; 8 juegos en el modelo $4 \times 4$ y 8 juegos en el modelo $5 \times 5$. Los 24 partidos se dividen a partes iguales por los niveles de menores de 8 y menores de 10 con un total de 88 niños participando. Para el instrumento de recolección de datos se utilizó el método de observación diferida donde se procedió a un análisis descriptivo de los datos para encontrar las medias, desviación típico y totales de: Disparos, Pases, Intercepciones y goles. Las pruebas de Mann-Whitney, Kruskal-Wallis se utilizaron para comparaciones y correlaciones, la Prueba de Spearman se utilizó para verificar si a medida que aumentaba el área de juego disponible para el jugador, las acciones del jugador también aumentaban. El modelo 3x3 obtuvo un total de 911 acciones, el modelo 4x4 obtuvo 923 y el modelo de juego $5 \times 5$ obtuvo 799 acciones de juego. El modelo de juego $4 \times 4$ obtuvo el mayor número total de acciones de juego en todos los niveles analizados sugiriendo que la implementación de este modelo trae beneficios a los atletas.

Palabras clave: Rink Hockey; Juegos reducidos; Niveles de formación; Niños; Modelos de juego.

\section{Introduction}

Team Sports (TS) are important in the training of children and young athlete's, since they promote fundamental values for their education (Mogadouro, 2012). The sports to be considered team sports should be based on three concepts: having teammates, having opponents and having a degree of uncertainty (Parlebas, 1987). Hockey, fits within the TS for containing these three concepts. Bayer (1994) considers that it is from the rules of action that team sports start to differentiate, and to take their specific outlines of actions, with the emergence

Fecha recepción: 18-02-21. Fecha de aceptación: 31-08-21

Samuel Honório

samuelhonorio@hotmail.com of the specific technical gestures of each sport, the basis of these technical gestures they are common elements among the TS, since there is a demand for common skills, which later become specific techniques for each sport. The TS, in addition to all their characteristics that have in their internal logic governed by the specific rules of each game, they can be modified in nonprofessional contexts of their practice, which is indicated in the sports initiation of athletes, so that it could be adapted the game to practicing contexts, aiming at its evolution (Paes, 2001; Riera et al. 2019; Clemente, Suárez-Arrones \& Gil, 2019). In a study of De Marco and Mello (2002) they argue that the ideal sport is one that should be based on the methodological assumptions of a pedagogy that respects its practitioners according to their age group, their motivations and their interests (López-Herrero \& Arias-Estero, 2019). Paes (2001) 
stresses that it is necessary to think about these practices with multiple possibilities, attending both to its practitioners, to occupy their free time, and to those who seek it for health issues. It is necessary to work with a sports initiation that allows a conscious practice. According to Gayo (1998), due to the special means of movement, rink hockey is an extremely fast game that involves great players mobility, forcing very quick and perspicuous actions and decisions, given that the game actions are performed in an attack situation, occupied by 8 athletes, where tactical reasoning is a fundamental component to increase performance in this sport.

The main objective of this study is to identify the game model that allows players to obtain a greater number of actions with the ball in rink hockey in the levels of «Under 8» and «Under 10», with specific objectives such as: 1) Knowing which game model guarantees more ball actions for all players; 2) Knowing if there is a relevant discrepancy in terms of game actions in athletes with the different game models; 3) Knowing which type of system guarantees the most finishing situations for each player.

\section{Small-sided games}

Small-sided games (SSG) are played, as the name implies, in fields with smaller dimensions and in which a smaller number of players is often used, when compared to a formal (full-sided) game, (Hill-Haas, Dawson, Impellizzeri \& Coutts, 2011). Also, according to Hill-Haas et al. (2011), one of the specific characteristics of small-sided games is the specific aerobic work involved. There are some studies (Romero-Caballero \& Campos-Vázquez, 2020) that establish comparisons between the Small-sided Team Sports Games (SSTSG) and the traditional aspects of training. Among these, what has been discussed are comparisons with interval training methods (Flores-Rodríguez \& Ramírez-Macías, 2020). At the competition level, the SSTSG are increasingly used as an alternative and efficient way for physical preparation, both generically and at intervals, to train movement patterns, physiological intensity and technical execution, so that they are thought through to reflect the competitive game and reduce the training volume (Lopez \& Gutiérrez, 2018). However, the realization of these advantages depends on the game model, which requires a good understanding of the variables that influence the prescription of training intensity of the SSG. The number of players is also a factor that can influence the intensity of the SSTSG. To study this variable, the number of players is changed, but the other characteristics remain constant, for example, the dimensions of the field. It is necessary to adapt the game to the child and not force the child to adapt to the adult game (Ferreira, 2013). Musch and Mertens (1991), recommend that each smallsided game must satisfy the following criteria: the objective of the game must always be present; all structural elements of the game must be preserved; attack and defense actions are always maintained; the natural transition from attack to defense should be possible; the situation must allow the choice of different possible solutions, so the tasks of the players must not be fully determined.According to Castelo (2003) framing training is to operationalize the criteria of analogous affinity between training and fundamental competitive situations. Carvalhal (2001) states that specificity has a coordinating effect on the entire process. Small-sided games allow more time spent on ball training under playing conditions compared to general training. Most exercises sessions in team sports, with the application of small-sided games, results in the use of a lower number of players in areas smaller than the official regular size of the playing field (Rampinini, Coutts, Castagna, Sassi \& Impellizzeri, 2007).

Small-sided games benefit children by making their first contacts with the game even more enjoyable and at the same time providing them with an environment that will facilitate further development of their skills (Torreblanca-Martínez, Ojeda \& González-Jurado, 2019). Children should be encouraged to maintain ball possession. In games with smaller fields and with a smaller number of players, the receiving and passing actions increase significantly, favouring a transfer of learning to the game situation. Castelo (2003), describes that the most used behaviours are the reception and pass actions. The training exercises for maintaining possession of the ball in smaller playing spaces, consist of a wide range of situations that can be conceptualized, through which one seeks to achieve greater security in maintaining possession of the ball in individual and collective terms, through of the systematic use of the following five factors: Field size, number of players, time, technical and instrumental. He also mentions that the exercises to maintain possession of the ball are established as general means of specific preparation for players and teams (Moniz, Clemente, Praça \& Costa, 2021). The exercises are characterized by the possibility of creating conditions that aim at tactical resolutions on the side of safety, that is, there is a collective effort, which prevents from attacking the opposing goal or if 
there are no favourable conditions to do so, it is preferable to keep ball possession, instead of taking the risk of «handing it over» to the opponent in an extemporaneous and thoughtless way. According to Rampinini et al. (2007), small-sided games are used by coaches for technical-tactical development and for improving aerobic fitness. Along with the field, there may also be variation in the number of players (Honório, Batista, Santos, Serrano, Petrica, Almeida \& Camões, 2021). These games are commonly used as part of structured training for players of all ages and levels. According to Hill-Haas et al. (2011), at the competition level, the SSG increasingly used as an alternative and efficient way for physical preparation, both generically and at intervals, to train movement patterns, physiological intensity and technical execution, so that are designed to reflect competitive play with less training volume (Cussaria et al., 2019; Sousa, Gouveia, Marques, Sarmento, Caldeira, Freitas, Lopes, Prudente \& Ihle, 2021). However, the realization of these advantages depends on the game model. This requires a good understanding of the variables that influence the prescription of training intensity of the SSG.

\section{Rink Hockey (Mini hockey)}

The Portuguese Hockey Federation (2014) identifies Rink hockey as an excellent «tool» for the growth, expansion and development of rink hockey, allowing children of both gender from 4 to 8 years old to have their first experience in the practice of this sport, which will open new horizons and opportunities to increase the number of practitioners, which can determine the improvement of their quality and capabilities. Rink hockey is originally the adaptation of the adult game to the needs and characteristics of children (Valente, 2007). According to Honório, Batista, Paulo, Serrano, Martins and Mesquita (2017) Mini hockey promotes greater technical-tactical action in the levels of Under 8 and Under 10, with greater interaction with the ball, thus becoming an excellent stage of teaching-learning for the $5 \times 5$ formal game on fields of official dimensions. Therefore, mini hockey is played in a field of smaller dimensions, with lighter balls, adapted hockey sticks to the child's size, as presented by Simões (2010) and with simplified rules, thus providing children with opportunities to develop their skills. The goal of mini hockey is to promote youth sports by focusing on the formative aspect of sport. Mini Hockey appears as a proposal for a progressive learning of the formal game of hockey $(5 \times 5)$. In addition to improving the technical skills of skating and stick/ball movements, the following notions should be introduced: Simplification of the rules, Modification of the playing field, variation / reduction of opposition and alteration of the specificities of the ball (size and weight of the ball). Graça and Oliveira (1995), consider that in the introduction of the game it is essential to isolate the disturbing factors of the success of the tasks, making it essential to adapt the game conditions such as:

The same authors present their proposal for learning / structuring the rink hockey game situation, which consists in the progressive realization of the following situations:

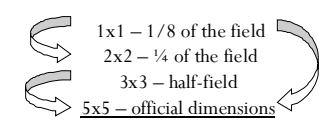

According to the facts mentioned above, we consider it premature to start approaching the game through the formal $5 \times 5$ situation. As Valente (2007) points out, the game for adults should be modified, adapting to the needs of children. Therefore, the introduction of the game should be carried out through situations that gradually increase in difficulty, from simple to more complex situations. However, based on the proposal of the Portuguese Hockey Federation (2014) for a simplified game, in the context of Mini hockey, based on the $3 \times 3$ game model, the intention is to analyse the game dynamics in the Under 8 and Under 10 levels, verifying if this adaptation translates into greater contact with the ball by the players and if the game becomes more interactive.

\section{Methods and Procedures}

\section{Participants}

The number of participants were 88 athletes, aged between 6 and 10 years old, who practice rink hockey since the age of 5 years. Our sample consisted of a selection of 24 games, from 4 different teams, of two levels, divided into: 8 games in the $3 \times 3$ game model; 8 games in the $4 \times 4$ game model and 8 games in the $5 \times 5$ game model. The 24 games are equally divided between the levels of Under 8 and Under 10 of 4 clubs with a total of 88 participating athletes. The $3 \times 3$ and $4 \times 4$ games will be played in half-field, measured between the midfield line and the back table, with the game played between the side tables. The $5 \times 5$ games are held in the context of a formal game with official dimensions. All levels and athletes included in the study were subject to the same conditions. 


\section{Statistical Procedures}

Before registering the different actions, a measurement was carried out in the observation process. First, the observers defined and learned the behaviours to be evaluated, discussing the categories among themselves, so that after observing the same time interval in a video and the behaviours of the same individual, both agreed (Petrica, 2003). For the interobserver evaluation, an excerpt from the first 3 minutes of a predefined game was analysed. To know the percentage of agreement between the observers, the Bellack formula presented and described below is used: $\%$ of Agreements $=$ (number of agreements) $/$ (number of agreements + number of disagreements) X 100.

Finally, we entered the data in the statistical analysis program SPSS Statistics 20, where the minimum, maximum, mean and standard deviation values are presented. Considering the number of games observed, non-parametric tests were used (Almeida \& Freire, 2000). Therefore, we used the Mann-Whitney test to compare two independent samples, the Kruskall-Wallis test to compare three or more independent samples, as well as to test correlations, we applied the Spearman correlation test.

The level of significance used to accept differences between groups and correlations between variables was 0.05 , which gives us a guarantee of at least $95 \%$ probability.

The reliability of the observation can be attested by the high percentage of registered agreements, which is at least $85 \%$, only with values equal to or greater than that the agreements are acceptable both in the intraobserver and inter-observer modality, as we can see in the following table:

Table 1

\begin{tabular}{ccc} 
Bellack indices agreements intra and inter observer. & \\
\hline Observed variables & \% Agreements Intra-Observer & \% Agreements Inter-Observer \\
\hline Shots & $100 \%$ & $100 \%$ \\
Passes & $92 \%$ & $92 \%$ \\
Goals & $100 \%$ & $100 \%$ \\
Tackles & $100 \%$ & $85 \%$ \\
Interceptions & $100 \%$ & $85 \%$ \\
\hline
\end{tabular}

\section{Procedures and Materials}

This study is considered quantitative as it uses numbers and uses quantitative variables. Allows you to know the most effective tactical process for the training of athletes, in terms of ball possession and other individual technical actions. It is descriptive, since we want to analyze the game's involvement through the shots made, the number of passes, goals, tackles and interceptions. It is also quasi-experimental as some variables are controlled, such as the type of training carried out on the day of the recordings: field size, playing time and number of players. This investigation can also be assumed to be quantitative in nature - quasi-experimental. In this sense, the study was developed by testing hypotheses and relationships between variables (Fortin, 1996). However, at the quasi-experimental level, it is not possible to control some parasitic variables that converge or may converge with the independent variable in explaining the results (Almeida \& Freire, 2008). Thus, the methodological design presents an experimental group, without recourse to an assessed control group, with the same group being assessed in different situations. A convenience sample was used, thus, some variables such as group selection or diversified interaction are properly controlled (Almeida \& Freire, 2008).

After acceptance of the proposal by the clubs, we proceed to deliver requests for informed consent to the parents of the players to record the games. We used the filming of several games and then recorded the number of actions by each player divided by total shots, shots on goal, total passes, right passes, short passes, long passes, interceptions and tackles, in both levels. The games were recorded through a Panasonic HCV180 Camera, to allow their repeated viewing if necessary, so that the registration of actions was more efficient. All the games analysed had a duration of eight minutes, in the respective fields of the participating clubs. As previously mentioned for the $3 \times 3$ and $4 \times 4$ game models, the area used was half-field $(20 \mathrm{~m} \times 20 \mathrm{~m})$, and in the $5 \times 5$ game model the area used was the entire field $(40 \mathrm{~m} \times 20 \mathrm{~m})$.

\section{Overall study objective}

- Identify the game model that allows players to obtain a greater number of actions with the ball in rink hockey in the levels of «Under 8 » and «Under 10».

Specific objectives

- Knowing which game model guarantees more ball actions for all players;

- Knowing if there is a relevant discrepancy in terms of game actions in athletes with the different game models;

- Knowing which type of system guarantees the most finishing situations for each player.

In terms of technical actions, the number of occurrences recorded in terms of Passes (Short and Long), Shots (on goal and out), time of action with the ball and goals conceded, saved shots, cuts and passes) and Goals for each of the $3 \times 3,4 \times 4$ and $5 \times 5$ game models. 
In terms of tactical actions, the number of occurrences recorded in terms of tackles and interceptions, made by players in each of the $3 \times 3,4 \times 4$ and $5 \times 5$ game models. The Area Actions Ratio (AAR) results from dividing the total of actions by the area of the field. Pass: The pass consists of a transmission of the ball between members of the same team. To that extent, it is a means that unites the intentions of the players and translates the

offensive cohesion of a team, which is why, in some cases, it functions as an important indicator for the characterization of the style and method of play practiced. This category will be divided into long passes and short passes. It is considered a long pass whenever the pass crosses 3 or more sections (according to Garganta, 1997) and a short pass whenever the pass crosses a lower number of sectors in relation to the previous one.

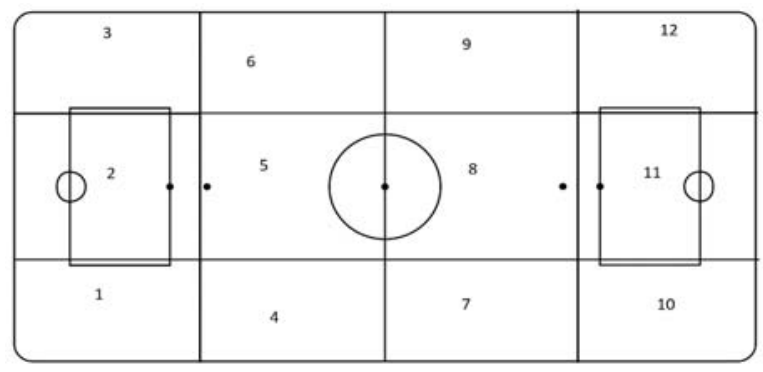

Figure 1- Field diagram of official dimensions (adapted from Garganta, 1997)

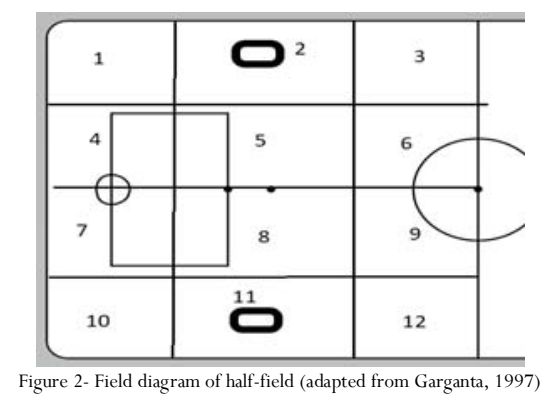

\section{Players Actions Analysed}

Tackling: Tackling or recovery is the result of specific defensive technical-tactical actions to conquer the ball from the opponent, being of two types, defensive recovery, made in the defensive zone, and offensive recovery, after momentary loss of the ball in the offensive zone;

Interception: An interception is considered whenever a player wins the ball after intercepting a pass by the opposing team's players.

Shot on goal: Hockey stick hitting action on the ball to achieve the purpose of the game, the goal. Shots on goal will be considered all balls aimed at the goal area, which hit the posts or bar, which are defended by the goalkeeper or goals.
Unsuccessful Shot: Any shot where the ball direction does not meet the previous requirements.

Actions: These are the total of all individual actions previously defined during a game.

\section{Results}

\section{Descriptive statistics}

This part presents the data collected from the assessment instruments, using the statistical and inferential analysis of the variables, which is presented from the tables.

\begin{tabular}{|c|c|c|c|c|c|c|c|c|c|}
\hline Zones & $\mathrm{Z4}$ & $\mathrm{Z} 5$ & Z6 & $\mathrm{Z7}$ & Z8 & Z9 & $\mathrm{Z} 10$ & Z11 & $\mathrm{Z12}$ \\
\hline $3 \times 3$ Under 8 & 2 & 0 & 1 & 1 & 24 & 6 & 15 & 53 & 2 \\
\hline $3 \times 3$ Under 10 & 0 & 3 & 3 & 10 & 18 & 8 & 10 & 56 & 7 \\
\hline $4 \times 4$ Under 8 & 0 & 2 & 1 & 13 & 7 & 5 & 12 & 49 & 9 \\
\hline $4 \times 4$ Under 10 & 0 & 2 & 0 & 8 & 16 & 8 & 5 & 53 & 8 \\
\hline $5 \times 5$ Under 8 & 0 & 0 & 0 & 2 & 0 & 2 & 6 & 48 & 2 \\
\hline $5 \times 5$ Under 10 & 0 & 0 & 0 & 1 & 4 & 1 & 5 & 50 & 3 \\
\hline Shots & 2 & 7 & 5 & 35 & 69 & 30 & 53 & 309 & 31 \\
\hline$\%$ Shots & $0,3 \%$ & $1,3 \%$ & $0,9 \%$ & $6,5 \%$ & $12,7 \%$ & $5,5 \%$ & $9,8 \%$ & $57 \%$ & $5,7 \%$ \\
\hline
\end{tabular}

According to table 2 the area 11 is where most of the shots take place (57\%), the area closest to the goal, also $71 \%$ of shots are made from a central area of the field (Zones 5, 8 and 11), and even as they move away from goal area, the percentage of shooting is constantly decreasing.

Table 3

Statistical data from the "Under 8" level

\begin{tabular}{lllllllllll} 
Number of players & TS & SoG & SM & TP & RP & SP & LP & I & T & Goal \\
\hline
\end{tabular} \begin{tabular}{ccccccccccc} 
Number of players & & & & & \\
\hline 3 & 29,25 & 25,25 & 4,00 & 35,00 & 24,75 & 19,50 & 5,25 & 10,25 & 14,50 & 5,25 \\
4 & 25,25 & 19,00 & 6,25 & 37,50 & 25,75 & 20,50 & 4,00 & 11,75 & 17,00 & 5,00
\end{tabular} $\begin{array}{llllllllll}25,25 & 19,00 & 6,25 & 37,50 & 25,75 & 20,50 & 4,00 & 11,75 & 17,00 & 5,00 \\ 13,75 & 11,50 & 2,25 & 46,00 & 34,50 & 30,25 & 4,25 & 11,25 & 16,50 & 2,00\end{array}$

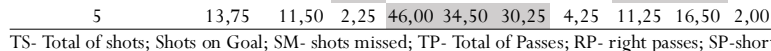
pass; LP-long pas; Int- Interceptions; T- tackles; G-Goals

In a first analysis the great differences between the small-sided games of $3 \times 3$ and $4 \times 4$ for the formal game $(5 \times 5)$ in the «Under 8 » level is mainly in the greater use of individual actions such as shots on goal and shots missed. When the formal game $(5 \times 5)$ is played, with the increase in the number of players and the size of the field, the players start to use a more collective dynamic, so they use more passes, but interestingly the largest number of long passes is in the $3 \times 3$ game and the highest number of tackles and interceptions in the $4 \mathrm{x} 4$ game model.

Analysing with more detail this level in the $3 \times 3$ game model it has more shots $(X=29.25)$, more shots on goal $(X=25.25)$, more long passes $(X=30.25)$ and more goals ( $X=5.25)$, the $4 \times 4$ model presents more interception situations in this level $(X=11.75)$, and tackles $(X=17.00)$ and the $5 \times 5$ game model obtains 
more passing situations ( $X=46.00)$, right passes $(X$ $=34.50)$, and short passes $(X=30.25)$. However, this game model, it is weaker than the other models in situations such as: total of shots $(X=29.25)$, the short passes $(X=24.75)$, right passes $(X=14$, 50) the interceptions $(X=10.25)$ and the disarms $(X=14.50)$. As for the $4 \times 4$ model, only long passes are at a disadvantage for the other two game models compared in this study $(X=4.00)$. And the $5 \times 5$ game model in this level does not allow for so many situations of shots ( $X=13.75)$, shots on goal $(X=11.50)$, shots outside $(X$ $=2.25)$ and goals $(X=2.00)$ as the other two systems analysed.

Table 4

Statistical data from the "Under 10 " level

\begin{tabular}{ccccccccccc}
\hline Number of players & TS & SoG & SM & TP & RP & SP & LP & I & T & Goals \\
\hline 3 & 29,75 & 23,50 & 5,25 & 41,25 & $32,0027,50$ & 4,50 & 9,25 & 16,50 & 6,25 \\
\hline 4 & 24,75 & 21,25 & 4,25 & 43,50 & $27,5022,00$ & 5,50 & 13,00 & 20,00 & 6,25 \\
\hline
\end{tabular} \begin{tabular}{lllllllll}
24,75 & 21,25 & 4,25 & 43,50 & $27,5022,00$ & 5,50 & 13,00 & 20,00 & 6,25 \\
\hline 17,00 & 14,00 & 3,00 & 46,75 & $33,5028,50$ & 5,00 & 12,00 & 14,25 & 3,00
\end{tabular} TS- Total of shots; Shots on Goal; SM- shots missed; TP- Total of Passes; RP- right passes; SP-short pass; LP-long pass; Int- Interceptions; T- tackles; G-Goals

Analysing the level of «Under $10 »$, the $3 \times 3$ game model shows more shots $(X=29.75)$, more shots on goal $(X=23.50)$, more shots missed $(X=5.25)$ and more goals ( $X=6.25$ ) exactly like the same number of goals in the $4 \times 4$ model that presents in this level more situations of long passes $(X=5.50)$, interceptions $(X=$ 13.00), and tackling $(X=20.00)$ and the $5 \times 5$ game model obtains more situations for passes $(X=46.75)$, right passes $(X=33.50)$, and short passes $(X=28.50)$. The lowest values in this level of the $3 \times 3$ game model are total passes $(X=41.25)$, long passes $(X=4.50)$, and interceptions $(X=9.25)$. The $4 \times 4$ model has weaknesses in relation to the other models in the right passes $(X=27.50)$ and in the short passes $(X=20.00)$. The $5 \times 5$ game model in this level does not show so many situations of shots $(X=17.00)$, shots on goal $(X$ $=14.00)$, shots missed $(X=3.00)$, tackles $(X=14.25)$ and goals $(X=3.00)$ like the other two systems analysed.

\begin{tabular}{|c|c|c|c|c|c|c|}
\hline \multicolumn{7}{|l|}{$\begin{array}{l}\text { Table } 5 \\
\text { Totals, me }\end{array}$} \\
\hline & $\begin{array}{l}3 \times 3 \\
\text { Totals }\end{array}$ & $3 \times 3$ & $4 \times 4$ & $4 \times 4$ & $5 \times 5$ & $\begin{array}{c}5 \times 5 \\
M \pm S D\end{array}$ \\
\hline Total of actions & 911 & $113,8 \pm 810,5$ & 923 & $115,38 \pm 17,62$ & 799 & $99,88 \pm 11,55$ \\
\hline Total of goals & 46 & $5,75 \pm 1,58$ & 45 & $5,63 \pm 2,13$ & 20 & $2,5 \pm 0,76$ \\
\hline Total of shots & 236 & $29,5 \pm 4,87$ & 200 & $25 \pm 4,10$ & 123 & $15,38 \pm 3,77$ \\
\hline Total of Passes & 305 & $38,13 \pm 5,64$ & 324 & $40,50 \pm 9,30$ & 371 & $46,38 \pm 7,96$ \\
\hline Total of tackles & 124 & $15,50 \pm 3,78$ & 148 & $18,50 \pm 6,23$ & 123 & $15,38 \pm 2,77$ \\
\hline Total of Interceptions & 78 & $9,75 \pm 2,71$ & 99 & $12 \pm 2,56$ & 93 & $11,63 \pm 2,38$ \\
\hline
\end{tabular}

The $4 \times 4$ game model is where there is a higher number of actions on the total of the games analysed $(t$ $=923 X=115.38 \pm 17.62)$, as well as a number of tackles $(t=148 X=18.50 \pm 6.23)$ and interceptions $(t$ $=99 X=12 \pm 2.56)$. In $3 \times 3$ games there are more shots $(t=236 X=29.5 \pm 4.87)$, and perhaps as a result of this indicator there are also more goals $(t=46 X=$ $5.75 \pm 4.87)$. In the $5 \times 5$ games, on the other hand, a highest number of passes is made $(t=371 X=46.38 \pm$ 7.96), taking these two factors aside, in the remaining parameters are less actions, less goals and less shots are the ones that present lower levels than the other two game models analysed. The remaining parameters (passes and interceptions) registered a lower level compared to the other game models in the $3 \times 3$ model.

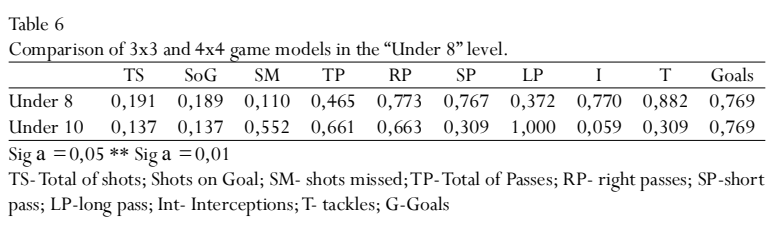

Through the Mann-Whitney non-parametric test, we resorted to a brief statistical analysis of the smallsided $3 \times 3$ and $4 \times 4$ games within the Under 8 and Under 10 levels and none of the game actions studied in both analysed levels registers a statistically difference between both game models.

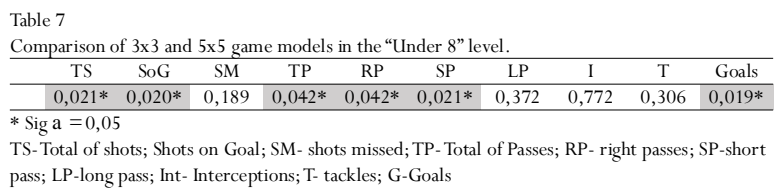

Using the same test (Mann-Whitney) for a comparison between the $3 \times 3$ game model with the $5 \times 5$ game, within the «Under 8 » level, we found that there are statistically significant differences $(p \mathrm{~d} \gg 0.05)$ in favour of the $3 \times 3$ game model in : Total shots per game $(p=0.021)$, on shots on goal per game $(p=0.020)$, total passes per game $(p=0.042)$, as well as right passes $(\mathrm{p}=$ 0.042 ), short passes ( $p=0.021)$ and the number of goals scored per game $(p=0.019)$.

Table 8

\begin{tabular}{|c|c|c|c|c|c|c|c|c|c|}
\hline TS & SoG & SM & TP & RP & SP & LP & I & $\mathrm{T}$ & Goals \\
\hline $0,018^{*}$ & $0,019 *$ & 0,186 & 0,561 & 0,773 & 0,770 & 0,882 & 0,191 & 0,564 & $0,013^{*}$ \\
\hline
\end{tabular}

Analysing the small-sided $3 \times 3$ game with the formal $5 \times 5$ game, within «under $10 »$, we find that there is statistical difference $(p d » 0.05)$ in favour of the $3 \times 3$ game in terms of: Total shots $(p=0.018)$ per game, shots on goal per game $(p=0.019)$ and the number of goals scored per game $(p=0.013)$.

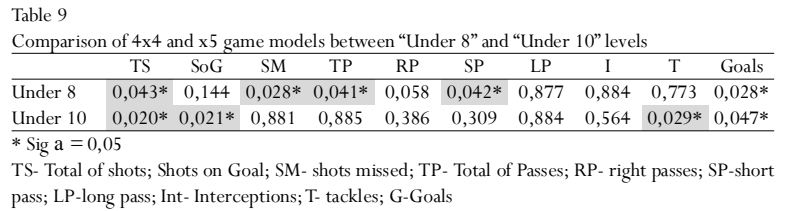


TS- Total of shots; Shots on Goal; SM- shots missed; TP-Total of Passes; RP- right passes; SP-short pass; LPlong pass; Int- Interceptions; T- tackles; G-Goals

Again, using the Mann-Whitney non-parametric test, this time comparing the $4 \times 4$ and $5 \times 5$ game models in both levels, in this comparison there are statistically differences $(p \mathrm{~d} \gg 0.05)$ in the «Under $8 »$ in total shots $(p=0.043)$, shots missed $(p=0.028)$, total passes $(p=0.041)$, short passes $(p=0.042)$ and goals $(p=0.028)$. In the «Under $10 »$, there are significant differences in total shots $(\mathrm{p}=0.020)$, shots on goal $(p=0.021)$, tackles

Table 10

Comparisons of Under 8 and Under 10 levels between $3 \times 3,4 \times 4$ and $5 \times 5$ game models. \begin{tabular}{lllllllllll}
\hline Game model & TS & SoG & SM & TP & RP & SP & LP & I & T & Goals
\end{tabular} $\begin{array}{lllllllllll}3 \times 3 & 0,554 & 0,766 & 0,297 & 0,139 & 0,149 & 0,083 & 0,544 & 0,663 & 0,375 & 0,356\end{array}$ $\begin{array}{lllllllllll}4 \times 4 & 0,554 & 1,000 & 0,306 & 0,384 & 0,885 & 0,561 & 0,766 & 0,468 & 0,386 & 0,462\end{array}$ $\begin{array}{ccccccccccc}5 \times 5 & 0,243 & 0,375 & 0,454 & 0,772 & 1,000 & 0,564 & 1,000 & 0,665 & 0,309 & 0,046 * \\ * \text { Sig a }=0,05 & & & & & & & & \end{array}$

TS- Total of shots; Shots on Goal; SM- shots missed; TP- Total of Passes; RP- right passes; SP-short pass; LP-long pass; Int- Interceptions; T- tackles; G-Goals

$(p=0.029)$ and goals $(p=0.047)$.

Table 10 refers that there are no significant differences $(p d » 0.05)$ in the comparison of Under 8 and Under 10 levels except for the $5 \times 5$ game in the number of goals per game $(p=0.046)$.

\begin{tabular}{cc} 
Table 11- Medium values of Area Actions Ratio & \\
\hline Field size & $\mathrm{M}$ \\
\hline Small-sided game & 1,8764 \\
Official dimensions & 0,9988 \\
\hline
\end{tabular}

When comparing the total number of players' actions towards the playing area, we can conclude that the number of actions per small-sided game area is much higher than the number of actions per area that each player occupies in the field with official dimensions $(1,8764>0,9988)$.

Table 12

Comparison between the total actions and Area Actions Ratio

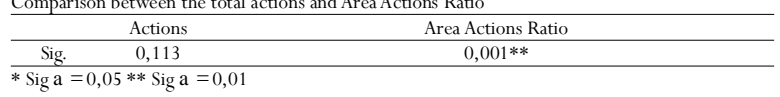

Through the Kruskal-Wallis non-parametric test, there are no statistical differences between actions per game in the different training game models of rink hockey. However, through the Area Actions Ratio (Sig $=0.001)$ its observable that as larger as the playing area is available to each player, the greater the number of actions occur in the game.

\begin{tabular}{ccc} 
Table 13- Comparison of Area Actions Ratio in the 3 game models & \\
\hline Game model & $\mathrm{M}$ & Sig \\
$3 \times 3 / 4 \times 4$ & $1,57-2,18$ & 0,007 \\
$3 \times 3 / 5 \times 5$ & $1,57-0,99$ & 0,001 \\
$4 \times 4 / 5 \times 5$ & $2,18-0,99$ & 0,001 \\
\hline Sig a $=0,05$ & &
\end{tabular}

Through the Mann-Whitney non-parametric its observable significant differences $(p \mathrm{~d} \gg 0.05)$ between all game models according to the field area available to play, and that the $4 \times 4$ game model allows the player to have more decisive actions in the game according to the field area and the number of players, and from the games analysed that the $3 \times 3$ game is more effective in terms of actions per player than the $5 \times 5$ game.

Table 14

Correlation of variables between Actions Area Ratio
$\begin{array}{ccccccc}\text { TS } & \text { SoG } & \text { SM } & \text { TP } & \text { RP } & \text { SP } & \text { L }\end{array}$

\begin{tabular}{|c|c|c|c|c|c|c|c|c|c|c|c|c|}
\hline & TS & SoG & SM & TP & RP & SP & LP & I & $\mathrm{T}$ & Actions & Ratio & Goals \\
\hline $3 \times 3$ & 0,15 & $-0,08$ & 0,31 & $\begin{array}{c}-0,32 \\
\end{array}$ & $\begin{array}{l}-0,23 \\
\end{array}$ & $-0,08$ & $-0,32$ & 0,39 & $-0,55$ & $-0,39$ & $-0,92 * *$ & $-0,08$ \\
\hline $4 \times 4$ & 0,45 & $-0,07$ & 0,37 & 0,30 & 0,39 & 0,24 & 0,16 & 0,41 & $-0,14$ & 0,46 & $-0,2$ & $-0,03$ \\
\hline Total & $-0,33$ & $-0,4$ & $-0,37$ & 0,26 & 0,40 & 0,02 & 0,23 & $-0,04$ & $-0,41 *$ & $-0,25$ & $-0,91 * *$ & $0,543 * *$ \\
\hline
\end{tabular}

Through the Spearman's correlation, in table 14 the $3 \times 3$ game, as the area ratio available for the player increases, it also increases; the number of shots, the number of shots on goal and the number of interceptions goes up. The number of shots missed, the total number of passes, as well as the short, long and right passes, as well as the number of actions and the number of goals per game are lower. The value of Actions Area Ratio drops significantly. In the small-sided $4 \times 4$ game with the increase in the playing area, the total number of shots, shots on goal, passes and interceptions increases. In a general interpretation, correlating all the games, as the playing area increases, the number of passes increases, in right passes, short and long, and the number of shots decreases, as well as shots on goal or shots outside, still interception passes and goals. The number of tackles, the number of goals and the actions ratio per game area also drop significantly, with a 95\% confidence interval and the remaining 99\%.

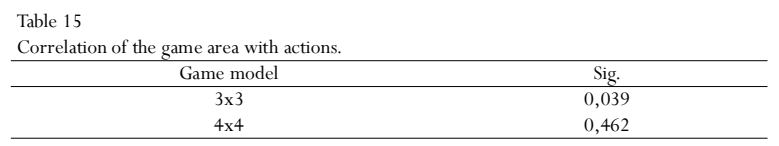

With the Spearman's correlation table to understand how, within the analysed field areas, they interfere with the game's actions, in the $3 \times 3$ game model as the playing area available to athletes increases, the number of actions goes down, already in the $4 \times 4$ game model as the playing area increases the number of game actions also increases. After testing the models for the playing area as a moderating and mediating variable in relation to the total number of actions, number of passes and goals, these models did not reveal any direct or indirect effects regarding the variable under study.

\section{Discussion}

In a first analysis that there are no significant differences according to the number of actions between 
the game of $3 \times 3$ and $4 \times 4$ in both levels analysed. However, according to Ferreira (2013) it is necessary to adapt the game to the child and not force the child to adapt to the adult game, so the $4 \times 4$ game model will still be beneficial for children because it allows a greater similarity with the game of adults.

Clemente et al. (2016) defend that the small-sided games increases the dynamics of the game, increases the actions with the ball so that it reaches the attack faster, like the pass and the shots. It appears that there are significant differences in the small-sided $4 \times 4$ game with the formal $5 \times 5$ game in the Under 8 . Hill-Haas et al. (2011) points out that the number of players is also a factor that can influence the intensity of the SSD. And after this analysis we realized that comparing these two types of small-sided game models in the level of Under 10 in the analysed games there are no significant differences in the game interactions. This aspect agrees with Hill-Haas et al. (2011), who emphasizes that the small-sided games bring more intensity than the formal games can obtain, emphasizing that the great advantage of the small-sided game depends on the several models of game adopted. And with this study we realized that there was much more intensity or better there were many more actions, offensive than defensive, than in the formal game, for example, there were many more goals and finishing actions with significant differences.

When comparing different levels where there are no significant differences in some variables, this study agrees with Vaz, Gayo, Valente, Coelho and Silva (2007) who studied ball possession in 12 complete semi-final and final games of the European Championship and the World Championship in the categories Under 17, Under 20 and Seniors, and noted that as the age of the groups increased, the possession of the ball increased. For Silva (2017) team sports games are characterized by their high unpredictability, great diversity and the constant search for decision making, so the games will be richer the more the number of decisions that each player makes during the game, either right or wrong. When comparing age levels in relation to their action's productivity, we realize that there are no significant differences in this case, which reveals that the fact that athletes can be more developed both physically and technically, as the games are levelled by this limit of both age groups provide their athletes with the same constant search for individual and collective decisionmaking and actions.

For Vaz (2000) one of the most important objectives of research inTS is to identify the factors that are directly linked to the performance and effectiveness of the players of a team, which complements our analysis where we realize that the only significant difference in the comparison of different ages, we realized that this factor (age) can influence the effectiveness of the players. Passos, Araújo and Davids (2013) address space-time interactions as one of the most limiting factors for players, which not agrees with this study that reveals that as the playing field increases, players' actions decrease. According to McGarry, Anderson, Wallace, Hughes and Franks (2002) they state that in game analysis it is essential to identify time-space patterns and how they can interfere with the behaviour of players and teams, which is seen in this study.

\section{Conclusions}

The game model with more finishing actions performed was in the $3 \times 3$ in which there were more shots (236) and more goals (46). It was also possible to verify that the zone where more shots were recorded was zone 11 (according to the field diagram) with more than $57 \%$ of the same achievements in that zone, and that it was in the $3 \times 3$ game that more short and long passes were recorded. This study also allowed to realize that in the analysed games its perceived that there is a lot of discrepancy in the analysed game dynamics. In first place, the small-sided games allows more game actions than the formal game, since the formal game allows only 0.99 actions per player per square meter while $3 \times 3$ allows 1.57 actions and $4 \times 4$ allows 2.18 actions which gives us a difference of 1.18 actions per player per square meter between the most productive diagram scheme and the least productive, which leads us to conclude that there are very discrepant differences between these game models, perhaps the $5 \times 5$ with all its breadth and complexity is still very demanding in physical and technical terms for the age group of the ages analysed since they are not so physically developed that their game is not as intense as in previous models, because in these levels the $5 \times 5$ becomes a very monotonous game.

Within the small-sided game models, $4 \times 4$ in a smaller field is what allowed children more actions and more experiences. But with this study its concluded that the game of $4 \times 4$ in a smaller field allows the players more preponderant actions in the game. In the games analysed, the $4 \times 4$ game model obtained a total number of 923 actions, slightly ahead of $3 \times 3$ with 911 . However, 
if we divide the total actions by the number of field players, then $3 \times 3$ allows a total of 303 to each field player and in turn the $4 \times 4$ game model only allows 230 actions per field player. Its concluded that the number of actions per player per square meter in the $4 \times 4$ is higher with 2.18 actions and the $3 \times 3$ only produces 1.57 actions. Continuing this analysis, it allowed to realize that within the amplitudes of fields analysed the small-sided game model $4 \mathrm{x} 4$ is the only one that increases the number of actions per game as the field increases. This allows to conclude that the implementation of the reduced $4 \times 4$ game model in the levels of Under 8 and Under 10 can be beneficial for the training of young rink hockey players.

\section{References}

Almeida, L. \& Freire,T. (2000). Meodologia de Investigação em Psicologia e Educação. Braga: Edições Psiquilíbrios.

Almeida, L. \& Freire,T. (2008). Metodologia da investigação em psicologia e Educação. Braga: Edições Psiquilíbrios.

Bayer, C. (1994). O Ensino dos Desportos Coletivos. Paris: Editions Vigot

Carvalhal, C. (2001). No treino de futebol de rendimento superior. A Recuperação é... Muitíssimo mais que «Recuperar». Braga: Edições Liminho.

Castagna, R., Belardinelli, R. \& Abt, G. (2004). The oxygen uptake and HR response to training with a ball in youth soccer players. Journal of Sports Sciences, 6: 532-544.

Castelo, J. (2003). Futebol - Conceptualização e organização prática de exercícios de treino de futebol. Ludens, 17: 35-44.

Clemente, F. (2016). Small-sided and conditioned games in soccer training the science and practical applications. Singapore: Springer.

Clemente, J., Suárez-Arrones, L. \& Gil, S. (2019). Differences between distinct spatial orientations based on individual player profile, Retos, 35: 3-6

Cussaria, J., Galvez, M., Alvarez, J. \& Gonzalez, G. (2019). Physical and physiological demands in women's field hockey: differences between play times. Retos, 35: 273-277.

De Marco, A. \& Mello, J. (2002). Desenvolvimento Humano, educação e esporte. In: Moreira, W.; Simões, R. (Org.). Esporte como fator de qualidade de vida. 2. ed. Piracicaba: Unimep, Brasil.

Duque, G. (2004). Estrutura interna do jogo de hóquei em patins: Estudo exploratório das posses de bola no escalão de juvenis masculinos. Dissertação de Licenciatura,
Faculdade de Ciências do Desporto e Educação Física, Universidade de Coimbra, Coimbra.

Federação de Patinagem de Portugal (2018). Regras do Jogo e Regulamento Técnico. Lisboa: Edições FPP.

Federação de Patinagem de Portugal. (2007). Regras do Jogo. Lisboa: Federação Portuguesa de Patinagem.

Federação de Patinagem de Portugal. (2013). Regras do Jogo. Lisboa: FPN.

Ferreira, L. (2003). Estrutura interna do jogo de hóquei em patins: Estudo exploratório das posses de bola no escalão de seniores masculinos. Dissertação de Licenciatura, Faculdade de Ciências do Desporto e Educação Física, Universidade de Coimbra, Coimbra.

Flanagan, T. \& E. Merrick. (2002). Quantifying the workload of soccer players. In:Science and Football IV.W. Spinks, T. Reilly, and A. Murphy, pp. 341-349. London: Routledge, Taylor \& Francis.

Flores-Rodríguez, J. \& Ramírez-Macías, G. (2020). One and two lines zone defence in small-sided games. Retos, 3: 604-61

Garganta, J. (1997). Modelação táctica do jogo de Futebol. Estudo da organização da fase ofensiva em equipas de alto rendimento. Dissertação de Doutoramento, FCDEF, Universidade do Porto, Porto.

Gayo, A. (1999). El hockey sobre patines como deportes de equipo - Análisis y optimización de los sistemas de juego a través de indicadores tácticos. Dissertação de Doutoramento. INEF, Galicia, La Coruña.

Graça, A. \& Oliveira, J. (1995). O ensino dos jogos desportivos o ensino do Basquetebol. $3^{\text {a Edição. }}$ Faculdade de Ciências do Desporto e Educação Física da Universidade do Porto, Porto.

Helgerud, J., Engen, L. C., Wisloff, U. \& Hoff, J. (2001). Aerobic endurance training improves soccer performance. Medicine and Science in Sports and Exercise, 33: 1925-1931.

Hill-Haas, S., Coutts, A., Dawson, B. \& Rowsell, G. (2010). Time-Motion Characteristics and physiological responses of Small-Sided Games in Elite Youth Players: Influence of Player Number and Rule Changes. Journal of Strength and Conditioning Research, 8: 2149-2156.

Honório, S., Batista, M. \& Martins, J. (2015). Dinâmica avaliada de jogo entre regras antigas e atuais no Hóquei em Patins. E-balonmano, 11: 83-84.

Honório, S., Batista, M., Paulo, R., Serrano, J., Martins, J. \& Mesquita, H. (2017) A importância do jogo MiniHóquei em patins nos escalóes de benjamins e escolares. XIII Seminário internacional de educação física lazer e saúde Instituto Politécnico da Guarda 10 a 11 Julho 
de 2017, Guarda.

Honório, S., Batista, M., Santos, J., Serrano, J., Petrica, J., Almeida, J. \& Camões, M. (2021). Small-sided games in the development of technical demands for young hockey goalkeepers. Journal of Physical Education and Sport, 21 (3): 1376 - 1382

Lopes, L. \& Gutiérrez, D. (2018). Contributions of the GPET to the GPAI: tactical context adaptation and game behaviour, Retos, 34: 323-328

López-Herrero, F. \& Arias-Estero, J. (2019). Effect of game form (5vs.5 and 3vs.3) on motor and psychological behaviours in under-11 basketball. Retos, 36: 354-361.

McGarry, T., Anderson, D., Wallace, S., Hughes, M. \& Franks, I. (2002). Sport competition as a dynamical self-organizing system. Journal of Sports Sciences, 20(10): 771-781.

Mogadouro, Â. (2012). Formação dos jogos desportivos coletivos. Tese de Mestrado, Faculdade de Ciências do Desporto e Educação Física Universidade do Porto, Porto.

Moniz, F., Clemente, F., Praça, G. \& Costa, I. (2021). Effect of outside floaters on soccer players' tactical behaviour in small-sided conditioned games, Retos, 42: 767-773

Musch, E. \& Mertens, B. (1991). L'enseignement dés sports collectifs: une conception elaborée à l'ISEP de Université de Gand. Revue de L'Education Physique, 31(1): 7- 20.

Paes, R. (2001). Educação Física escolar: o esporte como conteúdo pedagógico do ensino. Brasil: Ulbra Canoas. Revue Française de Sociologie, 28(3): 547-550.

Passos, P., Araújo, D. \& Davids, K. (2013). Selforganisation processes in team sports: Implications for leadership, Sports Medicine, 1(4): 1-7.

Petrica, J. (2003). A Formação de Professores de Educação Física. Vila Real. Dissertação de Doutoramento, Universidade de Trás-os-Montes e Alto Douro, Vila Real.
Parlebas, P. (1987). Eléments de sociologie du sport.

Rampinini, E., Coutts, A. J., Castagna, C., Sassi, R. \& Impellizzeri, F. (2007). Variation in top level soccer match performance, International Journal of Sports Medicine, 28(12): 1018-1024.

Riera, J., Tañá, G. \& Daza (2019). The Technical Skills of Rink Hockey Goalkeeper in Direct Free Hit. Retos, 36: 69-73

Romero-Caballero, A. \& Campos-Vázquez, M. (2020). Relationship between internal load indicators in a 3a-side small-sided game in young soccer layers, $R e$ tos, 37: 152-159.

Silva, A. (2017). Ensino dos jogos desportivos coletivos em contexto escolar. Tese de Mestrado, Universidade de Trás-os-Montes e Alto Douro, Vila Real.

Simões, J. (2010) Escala corporal comprimento do setique de Hóquei em patins e constrangimentos intrínsecos em crianças. Dissertação de Mestrado, Escola Superior de Desporto de Rio Maior, Rio Maior.

Sousa, H., Gouveia, É., Marques, A., Sarmento, H., Caldeira, R., Freitas, R., Lopes, H., Prudente, J. \& Ihle, A. (2021). The effect of balanced and unbalanced soccer small-sided games on the rating of perceived exertion in youth players, Retos, 41: 440-446.

Torreblanca-Martínez, V., Cordero-Ojeda, R. \& González-Jurado, J (2019). Analysis of physical and technical-tactical demands through small-sided games in semiprofessional football players. Retos, 35 : $87-90$

Valente, J. (2007). Modelo de formación de jovenes jogadores de Hockey sobre Patines. Faculdade de Ciências do Desporto e Educação Física da Universidade de Coimbra, Coimbra.

Vaz, V. (2000). Metrologia do Rendimento: Perfil Antropométrico e caracterização do esforço em jogadores juvenis de hóquei em patins. Dissertação de Licenciatura. Faculdade de Ciências do Desporto e Educação Física - Universidade de Coimbra, Coimbra

Vaz, V., Gayo, A., Valente, J., Coelho \& Silva, M. (2007). Análise do rendimento desportivo no hóquei em patins. Revista Portuguesa de Ciências do Desporto, 7(1): 83-84.
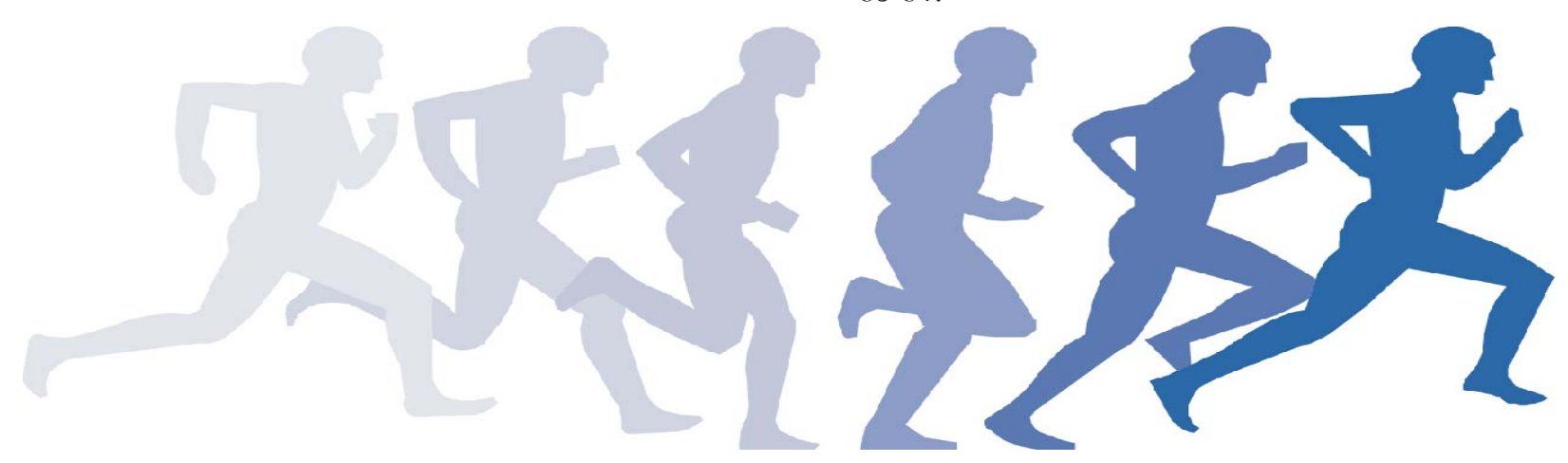